Đura Hardi ${ }^{*}$

Filozofski fakultet

UDK 929.731(437.4)"11/12"

Univerzitet u Novom Sadu

DOI: $10.19090 / \mathrm{gff} .2018 .1 .195-213$

\title{
PRVI POMEN GALICIJE U INTITULACIJI UGARSKIH KRALJEVA **
}

Istoriografija je saglasna da ugarski vladari, počev od Andrije II, u svoju intitulaciju kontinuirano unose i titulu kraljeva Galicije i Volinije (Galiciae Lodomeriaeque rex). Međutim, složenije je pitanje da li je Galiciju u svoju titulu prvi od ugarskih kraljeva već uneo Bela III, kako o tome svedoči jedan dokument skradinskog biskupa Mihajla od 2. maja 1189. godine. Pitanje je kontroverzno jer je reč o samo jednom pomenu sačuvanom u kasnijem prepisu. Autor iznova analizira verodostojnost ovog izvora. Iznosi mišljenje da u konkretnom slučaju po sredi nije morala biti greška ili falsifikat. Jedan od mogućih odgovora na efemernost pomena Bele III kao „rex... nec non Galacie” je okolnost da je ovaj pomen nastao pre dolaska cara Fridriha I Barbarose u Ugarsku na čelu krstaške vojske, i njegovog susreta sa Belom III (početkom juna 1189). U međuvremenu, knez Galicije Vladimir Jaroslavič, koji je dao povod ugarskom kralju da stekne vlast u Galiču, oslobodio se ugarskog ropstva i stao pod vlast i zaštitu rimsko-nemačkog cara. Čini se kao prihvatljiva pretpostavka da je upravo intervencija Fridriha Barbarose omogućila ne samo da se Vladimir bezbedno vrati na presto Galicije, već i da Bela III odustane od galičke titule.

Ključne reči: Galicija, Galicija i Volinija, Kraljevina Ugarska, knez Vladimir Jarolsavič, Bela III, car Fridrih I Barbarosa

Vladarske titule kao element istoriografske terminologije svoj nastanak temelje prevashodno na diplomatičkim izvorima, kao i na onim narativnim, koji često neposredno otkrivaju kontekst pojedinih istorijskih događaja. Pitanje - kada se Galicija prvi put našla u vladarskoj tituli ugarskih kraljeva - odavno je prisutno kod istoričara. Ovde nije bila reč samo o vladarskoj intitulaciji i pretenzijama ugarskih kraljeva na susednu zemlju s istočne strane Karpata, već po svemu sudeći i o najranijem latinskom terminu pomena imena "Galičine" u diplomatičkim izvorima zapadnog, odnosno, ugarskog porekla. Prateći zaključke naših prethodnika i njihove nedoumice u pogledu pojedinih odgovora, odlučili smo da pokušamo da damo novi doprinos ovoj istoriografskoj raspravi. Polazne tačke $u$ našem

*djurahardi@ff.uns.ac.rs 
istraživanju sadržane su u sledećim premisama. Pojava i nastanak određenih vladarskih titula nužno moraju biti potvrđene verodostojnim diplomatičkim izvorima, u onom njihovom delu koji se po pravilu odnosi na intitulaciju (intitulatio). $\mathrm{Na}$ drugoj strani, u proučavanju nastanka vladarskih titula za istoriografiju su skoro podjednako bitni i narativni izvori. Oni, da zaključimo, u krajnjem ishodu često jedini pružaju sliku o uzrocima i okolnostima nastanka titula. Drugim rečima rečeno, zahvaljujući analizi narativnih izvora, nove vladarske titule bivaju potencijalno smeštene $\mathrm{u}$ jedan širi, realan i logičan nadasve, istorijski kontekst.

Istoriografija je skoro jednoglasna u oceni da Galicija kontinuirano ulazi u titulu ugarskih vladara zajedno sa Volinijom u formuli Galiciae Lodomeriaeque rex za vladavine Andrije II, počevši od 1206. godine. Naime, pod tom godinom, na žalost bez dela datuma koji bi se odnosio na dan i mesec, sačuvan je sadržaj šest povelja u kojima se Andrija II u svojoj intitulaciji počeo izdavati za kralja pomenutih ruskih zemalja (F, III/1: 31-32, 33-35; F, III/2: 33-35; ÁÚO, VI: 307308; ÁÚO, XI: 87-85; H, VII: 2-4; RA: no. 222-226). Ovu diplomatičku praksu preuzeli su i svi njegovi naslednici na ugarskom prestolu sve do modernog doba. Što se tiče okolnosti koje su doprinele da ugarski kralj u svoju titulu unese Galiciju i Voliniju, na njih svojim dragocenim kazivanjem prevashodno upućuje Galičkovolinski letopis. Mada njegove vesti predstavljaju opšte mesto u istoriografiji, mi ćemo se ukratko zadržati na njegovom sadržaju. Naime, posle pogibije galičkovolinskog kneza Romana Mstislaviča tokom pohoda na Poljsku (19. juna 1205) (Holovko, 2001: 171-186), njegovi maloletni naslednici i država našli su se, takoreći, sa svih strana okruženi neprijateljima. Romanova udovica, koja je preuzela regenstvo, obratila se za pomoć ugarskom kralju Andriji II. Krajem leta ili tokom jeseni 1205. godine došlo je do vladarskog skupa u pograničnom galicijskom gradu Sjanoku (Hrtuševskij, 1901: 7, 61), na kom je ugarski kralj, u formi starateljskog (patronskog) prava, uzeo ,pod zaštitu” Romanovog sina i naslednika Danila Romanoviča (прияль бо бъ Данила како милог сына своего). Andrija II je uz to ostavio vojnu pomoć u Galiču koja je tek za izvesno vreme pomogla Romanovičima da sačuvaju presto Galicije i Volinije od drugih ruskih pretendenata (Ipatevskaja letopis: 717). Već naredne godine opet se ratovalo. Uprkos novom pohodu ugarskog kralja, Romanoviči su prvo izgubili Galič, a krajem te godine bili prinuđeni da napuste i prestoni grad Volinije, Vladimir. Burni galičko-volinski događaji 1205. i 1206. godine, složili su se istoričari, svoj formalno-pravni odraz imali su upravo u unošenju Galicije i Volinije u vladarsku titulu Andrije II. Za takav čin pravnu osnovu ugarskom kralju je davalo nekoliko okolnosti. On je stekao 
starateljstvo nad Romanovim naslednikom Danilom, a Romanova udovica je po našem mišljenju već na skupu u Sjanoku u ime svog sina priznala vrhovnu vlast ugarskog kralja, zauzvrat očekujući od njega vojnu podršku. Takođe se ne sme ispustiti iz vida da je jedan deo galičkih boljara, od kojih će tokom narednih decenija zavisiti sudbina zemlje, bio spreman da prizna vrhovnu vlast stranog vladara (Pauler, 1899: 48-49; Hruševskij, III, 19932: 18; Włodarski, 1925: 30; 1966: 35; Hómán, 1939: 434; Pašuto, 1968: 241-242; Kripjakevič, 1984: 88; Kristó, 1986: 101; Font, 1991: 121-122; 2005: 196; Majorov, 2001: 356; Kotljar, 2002: 99; Golovko, 2006: 260; Vološčuk, 2007: 17; 2008: 19, 22; Nagirnyj, 2011: 149; Dąbrowski, 2012: 34-45; Aleksandrovič - Vojtovič, 2013: 40-44; Vojtovič, 2015: 170-172). U svakom slučaju, kako je to već odavno zapaženo kod Đule Paulera i Bronislava Vlodarskog, u jednoj svojoj povelji sa tačnim datumom, 1. avgusta 1205. godine, Andrija II još uvek nije nosio intitulaciju kralja Galicije i Volinije. Nećemo stoga pogrešiti ako ovaj događaj odredimo kao datum post quem, ne samo skupa u Sjanoku, već i datum post quem sticanja nove ruske titule Andrije II (CDCr, III: 50-52; Pauler, 1899: 49, 494 ( ref. 48); Włodarski, 1925: 30; Vološčuk, 2007: 17). Kako smo u uvodnom izlaganju konstatovali, već naredne 1206. godine, stvari su se promenile u pogledu diplomatičkih izvora nastalih iz pera ugarske kraljevske kancelarije. I pored otežavajuće okolnosti što u toj godini nije sačuvan sadržaj ni jedne povelje Andrije II sa kompletnim elementima „datuma”, ipak, u svih šest sačuvanih on je bez izuzetka već nosio titulu Galiciae Lodomeriaeque rex (F, III/1: 31-32, 33-35; F, III/2: 33-35; ÁÚO, VI: 307-308; ÁÚO, XI: 87-85; H, VII: 2-4; RA: no. 222-226). U novijoj literaturi, Dariuš Dombrovski i Leontij Vojtovič (Dąbrowski, 2012: 36-44; Vojtovič, 2015: 171) na osnovu uporednih izvora i toka političkih zbivanja u Galiciji i Voliniji, odnosno onih na ugarskom dvoru, pokušavaju tačnije da odrede trenutak kada Andrija II tokom 1206. godine uzima titulu Galiciae Lodomeriaeque rex. Po mišljenju Dombrovskog to se zbilo u vreme drugog ruskog pohoda Andrije II (između marta i početka juna), a po rečima Vojtoviča posle rođenja Andrijinog sina i naslednika, budućeg Bele IV (druga polovina 1206.).

Nije teško zapaziti da je Andrijino vojno uplitanje u unutrašnje političke prilike u Galiciji i Voliniji bilo zapravo nastavak osvajačke politike koju je svojevremeno započeo njegov otac Bela III, a čiji je jedan od aktera bio i tada mladi Andrija. Međutim, dok je ugarsko vojno prisustvo u ruskim događajima iz 12051206. godine, kako smo videli, dobilo epilog u vidu formalnog unošenja dve ruske zemlje u kraljevsku titulu Arpadovića, pitanje da li se Galicija već tokom pohoda Bele III na Galič 1188. godine mogla naći u tituli ovog ugarskog kralja, još uvek nije dobilo konačan odgovor u nauci. Problem se u diplomatičkom smislu može 
svesti na činjenicu da je sačuvan samo jedan pomen Galicije u vladarskoj tituli Bele III, i to u dokumentu koji nije proistekao iz vladarske kancelarije. Pre nego što svoju pažnju posvetimo pitanju verodostojnosti tog diplomatičkog izvora, u duhu jedne od početnih premisa našeg istraživanja, zadržaćemo se na prikazu narativnih izvora, konkretno, saopštenja kijevskog letopisca, jer nam upravo njegove vesti bacaju neophodno svetlo na okolnosti koje su prvi put „dovele” Ugre u Galič.

Zbog svog političkog značaja, ali i nesvakidašnjih obrta koje nam opisuje pomenuti letopisac, prilike u Galiciji tokom 1188-1189. godine zauzimaju poznato mesto u istoriografskom diskursu (Font, 1987, 45-50; 2005: 179-187; Majorov, 2001: 274-296; Holovko, 2010, 116-132; Vojtovič, 2015:163-166). Ukratko, posle smrti kneza Galicije Jaroslava Osmomisla (1. oktobra 1187.), galički presto je uz pomoć boljara prigrabio njegov sin Vladimir Jaroslavič. „Galičanki muževi” i Vladimir su time pogazili datu zakletvu starom knezu da ga nakon smrti po njegovoj volji u bogatom Galiču nasledi njegov nezakoniti sin, istina miljenik, Oleg (Ipatevskaja letopis: 656-657). Sloga između boljara i novog vladara nije dugo potrajala. Po rečima letopisca, za to je bio zaslužan sam Vladimir i njegova loša narav. Navodno, Vladimir je bio odan prekomernom konzumiranju vina i u državnim poslovima se nije savetovao sa svojim boljarima. Oženio je jednu popadiju koja mu je rodila dva sina, a pored toga je, ako bi mu se dopala nečija žena ili kći, i njih ovaj napasnik kneževske krvi „uzimao na silu.” Nije prošlo ni jedna godina, a bahati nasilnik je već bio prinuđen da beži iz zemlje, budući da su njegovi nezadovoljni podanici podigli pobunu protiv njega sa ciljem da na presto dovedu kneza susedne Volinije, s naše strane već pominjanog, Romana Mstislaviča. Roman je naime bio u sprezi sa galičkim boljarima, vođama pobune. Uzevši sa sobom porodicu i državnu riznicu, Vladimir je sa svojom pratnjom utočište našao kod ugarskog kralja. Bela III mu je velikodušno obećao da će ga vratiti na presto njegovih predaka. I doista, Bela je na čelu velike vojske prešao Karpate i bez otpora Rostislaviča doveo u Galič iz koga je Roman Mstislavič pobegao glavom bez obzira, neslavno okončavši svoje prvo galičko kneževanje. Međutim, ugarski kralj je tada na galički presto postavio svog sina kraljevića Andriju, ujedno ostavljajući vlast u zemlji galičkim boljarima. Vladimira je kao sužnja odveo u Ugarsku, gde ga je sa porodicom zatvorio u jednu kamenu kulu. Zbilo se to, ne pre proleća, 1188. godine (Berežkov, 1963: 204; Font, 1987: 47-48). Međutim, borbe za Galiciju praćene brojnim preokretima, time nisu bile okončane. Pojavili su se ruski kneževi koji su nastojali da steknu vlast u Galiču i proteraju odavde inoplemene Ugre. Prikaz ovih događaja ostavićemo po strani, jer bi nas udaljio od glavne teme našeg rada. U međuvremenu, kako nas obaveštava ruski izvor, Vladimir je na hrabar i 
skoro neverovatan način (vredan pomena) uspeo da pobegne uz zatočeništva. Naime, na vrhu kule za uglednog zatvorenika beše podignut šator. Isekavši šatorsko platno, Vladimir je sebi ispleo konopac i spustio se niz zidine kule. On beše u dosluhu sa dvojicom stražara koji ga, bez sumnje za neku vrednu nagradu „доведоста земли Немъчкыя ко цареви НЪмъцкому”. Nemački car Fridrih I Barbarosa primio je vladara-begunca sa velikm počastima. Zaokupljen prečim planovima, car je u društvu svog izaslanika uputio Vladimira u Poljsku kod krakovskog kneza Kazimira Pravednog kome je naredio da ruskom knezu pomogne da stekne Galič. Jer, na kraju nam objašnjava letopisac, Vladimir se svojevoljno obavezao da caru plaća godišnji danak u iznosu od 2000 grivni srebra. Uz poljsku pomoć i podršku samih Galičana koji ,jedva dočekaše” svoga kneza, Ugri i kraljević Andrija behu proterani iz zemlje, a Vladimir je, na praznik Preobraženja Gospodnjeg (6. avgusta) 1189. godine kako to logično zaključuju Hruševski, Berežkov i Fontova (Hruševskij, II, 19922: 452-453; Berežkov, 1963: 204-205; Font, 1987: 47-49), ponovo seo na presto svoga oca (Ipatevskaja letopis: 659-667; Magistri Vincentii: IV, pars 15, 412-413). Bez sumnje, Vladimir je uspeo da se vrati na galički presto zahvaljujući okolnosti što je postao vazal cara Fridriha Barbarose, ili drugim rečima, što je stao pod njegovu vlast, dok mu je car, kako je i priličilo vrhovnom gospodaru, obezbedio pomoć i zaštitu. Doduše u jednom novijem istraživanju Mihail Jurasov, na osnovu analize poljskih narativnih izvora, iznosi zanimljivu pretpostavku da se Vladimir vratio u Galič ne početkom avgusta 1189, već naredne 1190. godine zbog navodnog sukoba do koga je u međuvremenu došlo između njega i Kazimira Pravednog (Jurasov, 2013: 67-77).

Mi smo ipak skloniji uvreženom mišljenju da je ugarska vlast u Galiču oličena u kneževanju mladog Andrije II mogla u najširem hronološkom okviru potrajati od proleća 1188. godine do avgusta 1189. godine. Upravo u tom periodu javlja se jedini pomen Bele III sa titulom kralja Galicije. Po sredi nije bila kraljevska povelja, već jedna isprava skradinskog biskupa Mihajla izdata 2. maja 1189. godine. Reč je dakle bila o privatno-pravnom dokumentu u kome je auktor iznova potvrdio dodeljivanje svog poseda u Bubnjanima kaluđericama Manastira Svetih Dimitrija i Tome u Zadru. Isprava je karakteristično započinjala sa formulom datacije „Anno ab incarnatione domini MCLXXXVIII, mense maii die II. astante, indictione VII., Jadre", da bi odmah u nastavku formule bilo istaknuto da se pravni čin zbio u vremena (temporibus equidem), ,domini nostri Bele gloriosissimi regis Ungarie, Dalmacie, Croacie Rameque nec non Galacie", kao i za dalmatinskog vicebana Makarija i splitskog arhiepiskopa Petra (Farlati, Illyrici Sacri, IV: 12; Katona, IV, 344-345; F, II: 247-248; Diplomatički sbornik HDS, II: 151; Ljubić, Libellus Policorion:179; CDCr, II, 234-235). 
Nažalost, u periodu od proleća 1188. godine do početka avgusta 1189. godine, kada je okvirno kraljević Andrija kneževao u Galiču, skoro da nije ostalo sačuvanih kraljevskih povelja koje bi nam posvedočile intitulaciju Bele III. Naime, za 1188. godinu poznat je sadržaj tri takva dokumenta. U Ostrogonu, 6. maja te godine, Bela je izdao jednu konfirmacionu povelju Manastiru Svetog Ivana u Biogradu u kojoj je tamošnjem opatu i bratstvu potvrdio ranije darovnice hrvatskih kraljeva za posede Rogovo, Vrbice i Kamenjana. Povelja je sačuvana u prepisu na pergamentu čuvanom u Zadarskom arhivu, kao i u kodeksu zvanom Libellus Policorion nastalom u drugoj polovini XIV veka o kome će biti više reči u daljem izlaganju. U njoj Bela III nije nosio titulu kralja Galicije, već je uobičajeno bio oslovljen samo kao „Hungarie, Dalmacie, Chroacie Rameque rex” (Ljubić, Libellus Policorion: 179; CDCr, II: 225-226; RA: no. 147) ${ }^{1}$ Možda se stoga 6. maj 1188. godine može uzeti kao datum post quem Belinog pohoda na Galiciju. Druga Belina povelja iz 1188. godine, navodna darovnica dela prihoda od ostrogonske skele izdata Ostrogonskom kaptolu, kako je odavno utvrđeno, predstavljala kasniji falsifikat (RA: no. 148; F, II: 244-245). Dalje, bez navedene godine, ali na osnovu njegovog sadržaja, istraživači dokument stavljaju u „oko 1188. godinu”, sačuvano je pismo Bele III upućeno engleskom kralju Henriju II Plantagenetu u vezi s njegovim planiranim prolaskom kroz Ugarsku tokom predstojećeg krstaškog pohoda. I ovde je izostala Galicija iz Beline intitulacije, ali zbog nepouzdane hronologije ovaj izvor je od ograničene vrednosti za našu temu (RA: no. 149; F, II: 246-247). Konačno, nije ostao sačuvan ni jedan sadržaj neke kraljevske povelje koja bi se odnosila na 1189. godinu (RA: no. 150). Nakon te godine znamo za još nekoliko dokumenata proisteklih iz kraljevske kancelarije Bele III koji nisu bili plod falsifikata (RA: no. 151-159). Istoriografija je već zapazila da se u njima titula rex Galicie ne pominje, međutim, sticajem okolnosti oni neće biti predmet našeg interesovanja. U tom pogledu, isprava skradinskog biskupa u kojoj je ugarski kralj oslovljen kao rex Galacie je doista jedinstvena.

Značaj ovog pomena zapazio je još u poslednjoj četvrtini XVIII veka znameniti izdavač srednjovekovnih izvora Kraljevine Ugarske, Stefan Katona, kada je, preuzimajući izvor iz prvog njegovog izdanja sačinjenog od strane Danijela Ferlatija (1769), razborito konstatovao da je 1189. godine Bela III pripravio (apparet), odnosno uzurpirao (usurpavit) titulu Galicije. Na taj način ovaj erudita je uveo pitanje prvog pomena termina titule rex Galacie u istoriografiju (Katona, IV,

\footnotetext{
$1 \mathrm{Za}$ verodostojnost i međusobnu relaciju dva prepisa pogledati komntare kod Tadije Smičiklasa i Šime Ljubića, kao i nezaobilaznog Imre Sentpeterija.
} 
344-345). Istina, od tad će proći više od jednog stoleća od kada je Mihajlo Gruševski u svojoj Istoriji Ukrajine-Rusi kritički sagledao ovu temu u svetlu burnih galičkih zbivanja na početku vladavine Vladimira Jaroslaviča. Gruševski je, naime, u vidu napomene izneo sumnju u verodostojnost konkretnog izvora, logično zapažajući da se radilo samo o jednom, „usamljenom” dokumentu koji tim više nije bio izdat od strane vladara, već jednog episkopa (Gruševskij, III 1993²: 449). Nakon Gruševskog, istraživačima je više-manje preostajalo da se priklone njegovom mišljenju ili da ga dovedu u pitanje. ${ }^{2}$ Vsevolod Pašuto je galičku intervenciju Bele III povezao sa navođenjem njegove nove titule u povelji od 2. maja 1189. godine (Pašuto, 1968: 180-182, 334). U novijoj istoriografiji, Marta Font (1987: 45-46; 2005: 187) smatra da je ugarska ekspanzija na zemlje s druge strane Karpata 1188-1189. godine imala svoj odraz u ,pravnoj tituli” Bele III, rex Galacie na koju se ranije nije moglo naići u izvorima. Uprkos okolnosti da je izdat od strane jednog biskupa, Leontij Vojtovič (2008: 4-5; 2015: 163-164) takođe ne dovodi u sumnju značaj ovog izvora, kao ni činjenicu da je Bela III bio prvi ugarski vladar koji je uzeo ovu titulu. Na drugoj strani, Mihail Jurasov (2013: 70) uvažavajući mišljenje Gruševskog, smatra da ne bi trebalo u potpunosti prihvatiti stav da je Galicija u vreme vladavine Bele III ušla $\mathrm{u}$ sastav titule ugarskih kraljeva. Na osnovu diplomatičke analize izvora, pri čemu su posebnu pažnju obratili na auktora, zanimljivo je mišljenje Đule Krišta i Ferenca Maka (Kristó -Makk, 1981: 20; Makk, 1982: 55; Makk, 1989: 121), izneto u njihovoj zajedničkoj studiji o Beli III. U kontekstu nedavnih Belinih vojnih uspeha u Dalmaciji i Galiciji, ovi autori su smatrali da su podanici ugarskog kralja u Dalmaciji nastojali da ga pridobiju i time, da su među njegove titule ubrajali i onu kralja Galicije. U jednom drugom radu Ferenc Mak (Makk, 2000: 176) je međutim bio još određeniji zaključivši da su doista „Dalmatinci” isticali da je njihov vladar kralj Galicije. Ali na drugoj strani, po mišlejnju Maka, Bela III u svojim poveljama ipak nije navodio ovu titulu, što se može objasniti činjenicom da je on nije ni uzeo niti da ju je koristio u svojoj intitulaciji.

Respektujući mišljenje Ferenca Maka, mi ipak ne mislimo da je kancelarija skradinskog biskupa, na moguću vest koja je stigla sa vladarskog dvora u Zadar o uspehu njihovog kralja u dalekoj Galiciji, tek tako samoinicijativno u njegovu titulu unela ovu rusku zemlju. Pre nam se čini da je ovdašnji pisar, odnosno sam biskup, potvrđujući svoju darovnicu kaluđericama Svetih Dimitrija i Tome, prilikom sastavljanja isprave kao obrazac za titulu vladara pred sobom imao neki zvanični

\footnotetext{
${ }^{2}$ Sadržajan pregled stavova istoriografije u vezi sa dokumentom od 2. maja 1189. godine daje Vitalij Nagirnij (Nagirnyj, 2011: 148) .
} 
dokument koji je u to vreme u Dalmaciju stigao iz kraljevske kancelarije u kome je doista Bela III i formalno nosio titulu rex Galacie. Tom prilikom pisar je zapazio da je Galicija u tituli bila novina, te je ispred nje upotrebio izraz nec non. Istine radi već smo konstatovali da kraljevski dokument sa takvim sadržajem titule nije ostao sačuvan, dok je Bela III vladao sve do 1196. godine! Takođe, u diplomatičkom smislu, isprava jednog dalmatinskog biskupa nije imala značaj kraljevske povelje i nije mogla biti dokaz zvanične kraljevske intitulacije. Smatramo, međutim, da se njeno realno postojanje ipak posredno moglo sačuvati upravo $\mathrm{u}$ ispravi nastaloj $\mathrm{u}$ Zadru tog 2. maja 1189. godine. Svakao, pod uslovom da je naš izvor verodostojan.

Nedavno je u svojim radovima novi prilog ovoj temi dao i Miroslav Vološčuk (2010: 63-66; 2014: 116). Po mišljenju ovog autora, moguće je da uzimanje titule rex Galaciae od strane Bele III nije imalo veze sa ruskom Galicijom, već sa maloazijskom Galatijom (Galatia; Г $\alpha \lambda \alpha \tau i ́ \alpha)$ i učešćem Mađara u krstaškoj vojsci Fridriha Barbarose koja je tokom 1190. godine prodrla u Malu Aziju. Sam Bela je, podseća ovaj autor, kao mlad odrastao na dvoru vizantijskog cara Manojla Komnina. Bio je carev naslednik i verenik njegove kćerke. Nosio je titulu despota i mogao je stoga dobiti na upravu neke oblasti Carstva, poput upravo Galatije. Belin „interes” za ovu maloazijsku oblast takođe je mogao imati uporište i u njegovom prvom braku sa antiohijskom princezom, carevom rođakom Anom, Agnezom, Šatijon (Anna, Agnes, Châtillon), kao i u Belinim vezama sa susednim Latinskim krstaškim državama. Ipak, smatramo da ovakvu hipotezu treba prihvatiti sa rezervom. Istoriografiji je naime dobro pozant Belin romejski period života, kao i njegovo sticanje nove i zvučne titule urum-despot. Ostalo je, međutim, nepoznato da je Bela (stvarno ili titularno) upravljao nekom od maloazijskih oblasti Vizantije. Za njegove zemlje držane su Dalmacija i verovatno Srem koje su se tada nalazile u sastavu Carstva (Moravcsik, 1953: 87-91; Ostrogorski, 1970: 205-218; Makk, 1982: 33-61; Makk, 1989: 122-124). Takođe, pitanje je u kojoj je meri u drugoj polovini XII veka u Vizantiji komninske epohe, kao i među njihovim savremenicima na Zapadu, ostalo sačuvano ime nekadašnje rimske (i vizantijske) provincije Galatiae, budući da je ova civilna provincija Carstva ,potrajala” do 8. veka, kada je postala deo teme Opsikije (Opsikion). Od tad njeno ime gubi administrativnu upotrebu i biva u narativnim izvorima svedeno samo na svoje geografsko značenje (Foss, 1991: 816). Konačno, Bela III je doista ustupio jedan odred svoje vojske na raspolaganje caru Fridrihu Barbarosi i njegovim krstašima tokom njihovog prolaska kroz nesigurne balkanske predele na putu ka Carigradu i dalje na istok 1189. godine. Kao što je poznato, čarke vizantijskih snaga i ovdašnjeg domaćeg stanovništva sa krstašima su neizbežno prerasle u otvoreni rat. Kada su trupe nemačkog cara zauzele romejski Plovdiv i 
spremali se da napadnu na samu prestonicu Carstva, Bela je novembra 1189. godine od Fridriha zatražio povlačenje svojih ljudi sa pohoda. Birajući između moćnog nemačkog i slabog grčkog cara, u trenutku kada je izgledalo da će Carigrad biti osvojen od krstaša, Bela se u skladu sa svojim interesima, zapravo od početka, opredelio za stranu svog zeta i saveznika, vizantijskog vasilevsa Isaka II Anđela. I pored poziva koji su mu ranije stigli od papstva i vladara latinskog Istoka, on nije pomišljao da ,uzme krst” i lično krene u krstaški rat. Fridrih Barbarosa je tada dopustio da glavnina ugarskih snaga na čelu sa đerskim biskupom i šest župana napuste krstaški tabor. Ipak, u daljem krstaškom pohodu ostao je jedan deo ugarskih vojnika (predvođenih trojicom župana). Teško je reći da li je ova okolnost mogla biti razlog što je njihov kralj još nekoliko meseci pre toga u svojoj tituli istakao pravo na maloazijsku Galatiju (Pauler, 1899: 3-5; Kristó, 1986: 98; Makk, 1982: 56; Makk, 1989: 122).

Pristupajući istraživanju koje ga je dovelo do navedenih pretpostavki, Miroslav Vološčuk (2010: 63; 2014: 116) je, s druge strane, sasvim utemeljeno svoju pažnju obratio i na verodostojnost izvora. Logično je primetio da je u jezičkom ili ortografskom pogledu pomen titule Bele III kao regem Galacie mogao biti posledica kancelarijske greške. Za razliku od unošenja Galicije u intitulaciju ugarskih vladara od 1205/6. godine u formi Galiciae [Lodomeriaeque] rex koja je imala kontinuitet i koja je postala kancelarijska norma, pomen iz 1189. godine bio je usamljen i efemeran. Ova pretpostavka postaje uverljivija ako se doda da se Galicija u formi Galacia u tituli Belinog sina Andrije II javlja samo jedanput, a sporadičnost ovog pomena zastupljena je još samo nekoliko puta kod poslednjih predstavnika loze Arpadovića. Da ne idemo dalje, u slučaju pomena Andrije II (bračni ugovor sa Beatriče Este iz 1234. godine), kako su to istakli izdavači ovog izvora, reč je bila o notarskoj ispravi sačuvanoj u prepisu iz Modenskog državnog arhiva koji je obilovao grešakama. One su mogle poticati ili iz nekog ranije iskvarenog izvora, ili ih je trebalo pripisati prepisivačima dokumenta. Bilo kako bilo, tom prilikom titula Andrije II je pored leksičkih i ortografskih lapsusa bila ,ispremetana” te su se Galicija i Volinija (laudemieque Rex) našle razdvojene (Ho: 1-3; RA: no. 167). Što se tiče sporne upotrebe forme Galacia kao latinske varijacije koja je trebalo da se odnosi na ime istočnoslovenske Galičine, ona moguće da i nije bila greška. Ako je uslovno i bila greška, moramo se staviti u položaj nekog dotičnog pisara koji je slovensko ime te zemlje pokušao da prevede, odnosno latinizuje $i$ unese $u$ intitulaciju svog vladara. Na primer, u jedinoj sačuvanoj originalnoj povelji (!) koja je izašla iz njegove latinske, kneževske kancelarije oko 1257. godine, prognani u Ugarsku galički knez Rostislav Mihailovič je u svojoj intitulaciji oslovljen, takođe, kako „Nos Rozlaus Dux Galacie...... ”. Hipotetički gledano, Rostislavljev notar je rutinski morao „znati” kako 
se piše titula njegovog gospodara (Dl. 83038; Z, I: 5-6). Moguće da je takav slučaj bio i te 1189. godine, ako ne na kraljevskom dvoru, onda u sredini dalmatinskih pisara u službi Skradinske i Zadarske crkve. U tom slučaju, termin Galacia bio bi najstarija transkripcija istočnoslovenskog imena Galicije u jednom latinskom diplomatičkom izvoru (ovom prilikom narativni izvori ne ulaze u predmet našeg istraživanja). Ali, da se vratimo na već ranije postavljeno pitanje - da li je isprava skradinskog biskupa Mihajla verodostojna?

Poput brojnih drugih diplomatičkih izvora iz XII veka, isprava skradinskog biskupa do istoričara nije stigla u originalu. Njen prepis ostao je sačuvan u poznatom kodeksu Libellus Policorion, qui Tipicus vocatur koji se danas čuva u Državnom arhivu u Zadru. ${ }^{3}$ Po sredi je bila jedinstvena zbirka dokumenata o posedima i prihodima benediktinskog Manastira Svetog Kuzme i Damjana na ostrvu Pašman i njegovog starijeg prethodnika, razrušenog Manastira Svetog Ivana Evanđeliste u Biogradu. Na 41. foliji uvezanoj u četiri sveske može se pratiti rukopis dvojice pisara koji su po svemu sudeći krajem 60-ih ili početkom 70-ih godina XIV veka sastavili zbirku za potrebe ovdašnjeg opata. Od 133 isprava i zapisa najstariji se odnosi na XI vek (1060). Kodeks je u celini, sa uvodnim komentarima, publikovao Šime Ljubić 1890. godine (Ljubić, Libellus Policorion: 154-219). Poslednji u nizu istraživača koji je raspravljao o verodostojnosti Policorion-a jeste Tomislav Galović (2012) čija nam je doktorska disertacija nažalost ostala nedostupna, mada nam je od koristi bio njen sažetak. Sam Galović konstatuje da u istoriografiji postoje različita mišljenja o verodostojnosti zbirke. On međutim zaključuje da je teško razlučiti one isprave koje su falsifikati od onih verodostojnih. U kartularu se svakako nalazi određen broj diplomatičkih falsifikata, ali ni za jedan od njih nije moguće sa sigurnošću ustanoviti da su istorijski falsifikati. Njihov sadržaj je u svakom slučaju jedinstven i u većini slučajeva u pogledu diplomatičke i filološke analize pouzdan i vjerodostojan.

Ako analiziramo sadržaj isprave skradinskog biskupa Mihajla nastale 1189. godine, uz neizbežan oprez čini nam se da je on verodostojan. Pored toga, koliko je nama poznato, taj sadržaj nije osporen kao falsifikat u istoriografiji. Auktor isprave, biskup Mihajlo, istorijska je ličnost, posvedočena u drugim izvorima, koja je dve decenije bila prvosveštenik skradinske crkve (1179-1199) (CDCr, II: 453). Dalmatinski viceban Makarije, naveden u uvodnom delu povelje, takođe je bio autentična ličnost, dugogodišnji državni velikodostojnik Arpadovića (CDCr, II: 446; Klaić, 1988: 206; Zsoldos, 2011: 326), kao i tom prilikom pomenuti splitski

\footnotetext{
${ }^{3}$ Državni arhiv u Zadru (DAZD), Spisi samostana Sv. Kuzme i Damjana (SSKZ), sign. HRDAZD-337, br. 1. Libellus Policorion (LP), navedeno prema Galović, 2012: 103-116.
} 
nadbiskup Petar (CDCr, II: 464. Novak, 1957: 93-95). Ne smemo takođe staviti u drugi plan ni okolnost da je ugarski kralj u ispravi naveden kao rex Galacie u trenutku kada se njegov sin Andrija okružen ugarskom posadom doista nalazio na galičkom prestolu. Sudbina pravnog čina isprave, odnosno sudbina poseda u Bubnjanima, takođe se može pratiti na osnovu više izvora, istina, pre svega zahvaljujući prepisima sačuvanim u nezaobilaznom Policorion- $u$. Naime, još marta 1181. godine, izvesnu zemlju koja je ležala u Bubnjanima, a koju su nezakonito prisvojili „Saracenus filius Besciani” i izvesni Bruconia, skradinski biskup Mihajlo dodelio je Manastiru kaluđerica Svetih Dimitrija i Tome u Zadru, budući da je taj posed pripadao njegovoj crkvi (CDCr, II: 171-172; Ljubić, Libellus Policorion: 179-180). Nakon toga, biskup je u nama već dobro poznatoj ispravi od 2. maja 1189. godine po drugi put potvrdio svoju sudsku odluku u vezi sa posedom u Bubnjanima. Kada je krstaška vojska Četvrtog krstaškog pohoda 1202. godine za račun Mlečana osvojila i razorila Zadar, kaluđerice iz Crkve Svetih Dimitrija i Tome bile su prinuđene da napuste grad. Jedna grupa se sklonila na manastirski posed u Bubnjanima, da bi na kraju, 21. marta 1207. godine, pritisnute brojnim teškoćama preostale četiri kaluđerice svoju monašku zajednicu sa ovdašnjim posedom i Crkvom Svetog Petra stavile pod zaštitu opata Manastira Svetog Kuzme i Damjana na Pašmanu (Ostojić, 1964: 93-94, 242).

Kako onda možemo objasniti usamljeno navođenje galičke titulature Bele III u pomenutoj ispravi skradinskog biskupa ako apriori odbacimo mogućnost da je reč bila o grešci, naknadnoj interpolaciji u nekom transumptu ili pak o samostalnom činu ispisivanja vladareve intitulacije od strane njenog auktora. Uzdajući se u sve što smo do sada rekli, mislimo da ipak možemo dati logično objašnjenje, iznoseći jednu pretpostavku koju bi svakako valjalo prihvatiti samo kao moguće rešenja našeg „problema”. Bez obzira što je Belina titula rex Galacie Miroslava Vološčuka „krstaškim itinerarijumom” odvela u maloazijsku Galatiju, ovaj autor je, po našem mišljenju, vrlo razložno primetio određenu kontradiktornost. Za njega je ostala „zagonetna" okolnost kako je Bela III mogao preko svoje titule da istakne pravo na Galiciju, ako je nemački car Fridrih Barbarosa neposredno pre odlaska u krstaški pohod postao zaštitnik Vladimira Jaroslaviča i formalni sizeren njegove države. Ova okolnost postaje zagonetnija ako se zna da je Bela odustao od galičke titule i pretenzija uprkos tome što je car uskoro poginuo (10. juna 1190) (Vološčuk, 2010: 65). Smatramo da objašnjenje ove okolnosti možda leži u hronologiji događaja koji su formalno uredili odnos između trojice vladara i definitivno omogućili Vladimirov povratak na galički presto.

Kada je Vladimir pobegao iz zatočeništva i kada je mogao stati pod zaštitu nemačkog cara? Uporednim istraživanjem ruskih letopisa i zapadnih hroničara ovom pitanju posebnu pažnju je u svojoj studiji o hronologiji galičkih pohoda Bele III 
posvetila Marta Font (1987: 45-49). Njena zapažanja će nam svakako biti od koristi. Naime, zahvaljujući kazivanju ruskog pisara, znamo da se Vladimir u jednom pogodnom trenutku sretno oslobodio ugarskog zatočeništva $\mathrm{i}$ da su ga njegovi pomagači doveli do „Nemačke zemlje”, sve „do cara” s kojim se Vladimir i susreo na njegovom dvoru (Ipatevskaja letopis: 666). Fontova je primetila da se Fridrih Barbarosa 28. maja 1189. godine nalazio na granicama Ugarske, proslavljajući praznik Duhova u pograničnom ugarskom Presburgu (Bratilsavi) (Anno dominice incarnationis 1189. Fridericus imperator in pentecoste generalem curiam Prehsburc in markia Ungarie celebrans) (Font, 1987: 48; Ottone Sancti Blasii: 319-320).

Zapravo, krstaška vojska se na čelu sa carem već 24 . maja utaborila na zapadnoj granici Ugarske, na pustoj poljani nasuprot Presburga (između Lajte i Dunava, verovatno u oblasti Kittsee /Köpcsény) koja se narodnim jezikom zvala Viruelde (Virvelt) gde su krstaši ostali četiri dana (... profectus terram Vngaricam que extra portas dicitur, VIIII kal. iunii cum exercitu domini [Imperatoris] intravit et in planitie camporum qui vulgo Viruelde dicuntur, iuxta Bosonium urbem castra metati per quator dies ibi consederunt). 4. juna 1189. godine Bela III je svečano dočekao u Ostrogonu Fridriha Barbarosu, pruživši mu dostojno gostoprimstvo na putovanju kroz svoju zemlju (Ansbert: 17, 25; Riezler, 1869: 27; Pauler, 1899: 2).

Da zaključimo. Vladimirovo bekstvo, prijem na carskom dvoru (koji je moguće već bio u pokretu, tj. u krstaškom pohodu (Font, 1987: 48) i stavljanje ruskog kneza i njegove države pod seniorsku zaštitu Fridriha Barbarose zbilo se negde na nemačkom tlu, a pre carevog stupanja u Ugarsku i susreta sa ugarskim kraljem, dakle, svakako pre početka juna 1189. godine (datum ante quem: 28, odnosno 24. maj 1189), dok se jedini sačuvani pomen Bele III kao kralja Galicije hronološki odnosio na 2. maj 1189. godine, znači, na period pre susreta nemačkog cara sa svojim ugarskim domaćinom. Tokom lova na Čepelskom ostrvu, te nezaobilazne razonode svih vladara koja se odužila na četiri dana, ili za kraljevskom trpezom u Ostrogonu i Budimu, car i kralj su svakako vodili brojne političke pregovore (Pauler, 1899: 3-5, 482). Mada ne nailazimo na njenu neposrednu potvrdu u izvorima, naša pretpostavka je nadamo se sasvim logična. Fridrih i njegovi savetnici su tom prilikom, ugarskom kralju i njegovom dvoru neposredno skrenuli pažnju da se knez Galicije, Vladimir i njegova država od nedavno nalaze pod vrhovnom vlašću i zaštitom cara. Interes carskog dvora svakako je imao pokriće u obećanih 2000 grivni srebra, godišnjeg danka iz Galicije, ne ulazeći u pitanje da li su one ikad bile isplaćene (Jurasov, 2013: 69). Bilo je to „dovoljno” da Bela III odustane od pomisli da i dalje u kraljevskim poveljama nosi titulu rex Galacie. Bilo bi posve provokativno da u zvaničnim dokumentima ističe pravo na zemlju koja je priznavala vlast moćnog nemačkog 
vladara. Zaokupljen boravkom krstaša u Ugarskoj i njihovim daljim prodorom prema Carigradu, zaokupljen zapravo prisustvom vrlo moćnog gosta od čijih planova je svakako strepio, Bela III je odustao od svojih galičkih pretenzija. Po svemu sudeći, ovi detalji nisu ostali poznati ruskom letopiscu, niti poljskom hroničaru Vincentu Kadlubeku, ali svakako da su uticali na kraj kneževanja Belinog sina, Andrije u Galiču i njegov skorašnji „brzi povratak” u otadžbinu (početkom avgusta 1189. godine).

Pitanje - zbog čega Bela III nije obnovio svoju politiku prema Galiču posle 1190. godine - vrlo je važno, ali ono prevazilazi okvire našeg priloga i zaslužuje da bude razmatrano u nekoj drugoj raspravi. Kontinuitet politike dinastije Arpadovića prema Galiciji postojao ipak je i jasno je bio vidljiv u zbivanjima koja su usledila $\mathrm{u}$ državi Romanoviča tokom 1205-1206. godine. Uzrok ugarskih pretenzija valjalo bi tražiti ne samo u unutrašnjim prilikama u Galiciji, već i u snaženju Ugarske u međunarodnim odnosima nakon smrti vizantijskog cara Manojla Komnina (1180). Pozicije Vizantijskog carstva koje se nezaustavljivo povlačilo u pravcu svog sunovrata 1204. godine, između ostalih sila u usponu, nastojala je da zauzme i Ugarska koja za vladavine Bele III po prvi put ističe svoje pretenzije ne samo prema Galiciji već i susednoj Srbiji (Laurent, 1941: 109-129; Radojčić, 1954: 1-21). Manifestacija tih pretenzija bila je, po našem mišljenju, moguća i kratkotrajna upotreba titule rex Galacie u vladarskom naslovu Bele III, pod uslovom ako prihvatimo za verodostojan dokument izdat od strane skradinskog biskupa Mihajla u Zadru 2. maja 1189. godine.

Đura Hardi

\author{
Đura Hardi \\ THE FIRST MENTION OF GALICIA IN THE INTITULATION \\ OF HUNGARIAN KINGS
}

\title{
Summary
}

Royal titles as an element of historiographic terminology should base their creation primarily on diplomatic sources. However, it is also possible to take into account narratives, which often directly reveal the context of certain historical events. Historiography unanimously agrees that, beginning with Andrew II (1206), Hungarian rulers continually included the title of the King of Galicia and Volhynia (Galiciae Lodomeriaeque rex) in their royal intitulation. However, a significantly more complex question is whether it was in fact Béla III who was the first Hungarian king to include Galicia in his title, as can be found in a document by Michael, the bishop of Skradin, dated $2^{\text {nd }}$ May 1189 . This is a controversial 
question since the evidence in its favour includes only a single mention recorded in a later copy of the document. The author of this paper conducts a fresh analysis of the credibility of this source, putting forth a view that in this specific case, the reference was neither a mistake, nor a forgery. One of the possible answers for the ephemeral mention of Béla III as the „rex... nec non Galacie” was that it appeared (and that it was used) before the arrival of Emperor Frederick I Barbarossa ahead of the crusader army to Hungary, and his encounter with Béla III (in early June 1189). In the meantime, Galician prince Vladimir Yaroslavich, who was the reason why the Hungarian king gained power in Galicia, set free of the Hungarian oppression as he secured the protection of the Roman-German emperor. It can be assumed that it was the intervention of Frederick I Barbarossa that not only made it possible for Vladimir to safely return to the Galician throne, but also discouraged Béla III from further pressing the title of the king of Galicia and his Rus' aspirations.

Key words: Galicia, Galicia and Volhynia, Hungarian Kingdom, prince Vladimir Yaroslavich, Béla III, Emperor Frederick I Barbarossa.

\section{IZVORI}

\section{Nepublikovani izvori}

Dl = Magyar Országos Levéltár, Budapest, Mohács etőtti gyüjtemény (Collectio Antemohacsiana).

Državni arhiv u Zadru (DAZD), Spisi samostana Sv. Kuzme i Damjana (SSKZ), sign. HR-DAZD-337, br. 1. Libellus Policorion (LP)

\section{Publikovani izvori}

Ansbert $=$ Ansbert, Historia de expeditione Friderici Imperatoris. in: MGH SS, nova series, vol. 5, Quellen zur Geschichte des Kreuzzuges Kaiser Friderichs I, Chroust, A. ed. Berlin 1928.

ÁÚO = Árpád-kori új okmánytár. Wenzel G. ed., vol. I-XII, Pest-Budapest 18601874.

CDCr = Codex Diplomaticus Regni Croatiae, Dalmatiae et Slavoniae - Diplomatički zbornik kraljevine Hrvatske, Dalmacije i Salvonije. Smičiklas, T. ed., I-XIV, Zagreb 1904-1916.

Diplomatički sbornik HDS = Diplomatički sbornik kraljevine Hrvatske s Dalmacijom i Slavonijom, Codex diplomaticus regni Croatiae, Dalmatiae et Slavoniae. Kukuljević Sakcinski I. ed., II, Zagreb, 1876.

$\mathrm{F}=$ Codex diplomaticus Hungariae ecclesiasticus ac civilis. Fejér Gy. Ed., I-XI Budae 1829-1844. 
Farlati, Illyrici Sacri = Daniele Farlati, Illyrici Sacri, Ecclesiae suffraganeae metropolis Spalatensis. IV, Venetiis 1769.

Ho = Hazai oklevéltár 1234-1536. Nagy, I. -Deák, F. és Nagy Gy. eds., Budapest 1879.

H = Hazai okmánytár. Codex diplomaticus patrius. Nagy I. - Ráth K. -. Véghely D. eds., I-VII, Győr, Budapest 1865-1891.

Ipatevskaja letopis = Polnoe sobranie russkih letopisej. II, Ipatevskaja letopis, Sachmatov A. A. ed., St. Petersburg 1908. [Полное собрание Русских летописей, томъ второй, Ипатьевская летопись, (приготовлена А. А. Шахматовым), С. Петербург, 1908.]

Katona = Stephanus Katona, Historia Critica Regum Hungariae stirpis Arpadianae, Complectens Res Gestas Stephani III. Ladislai II. Stephani IV. Belae III. Emerici, Ladislai III. tomulus IV, Posonii-Cassoviae 1781.

Ljubić, Libellus Policorion = Ljubić Š., Libellus Policorion, qui Tipicus vocatur. Starine, XXIII, 1890.

Magisteri Vincentii = Magistri Vincentii Chronicon Polonorum, in: Monumenta Poloniae Historica. Pomniki Dziejowe Polski, ed. August Bielowski, vol. 2, Lwów 1872.

Ottone Sancti Blasii = Frisingensi episcopo conscripti continuatio auctore, ut videtur, Ottone Sancti Blasii monacho. Wilmans, R. ed. in: MGH, SS, XX, Pertz, G. H. ed., Hannoverae 1868.

$\mathrm{RA}=$ Az Árpád-házi királyok okleveleinek kritikai jegyzéke. I-II/1. Szerk. Szentpétery Imre. Bp. 1923-1943; II/2-3. Szerk. Szentpétery Imre-Borsa Iván. Bp. 1961; II/4. Szerk. Borsa Iván. Bp. 1987.

$\mathrm{Z}=A$ zichi és vásonkeői gróf Zichy-család idösb ágának okmánytára. Codex diplomaticus domus senioris comitum Zichy de Zich et Vasonkeo. I-XII, Pest, Budapest, 1871-1931.

\section{LITERATURA}

Aleksandrovič, V. - Vojtovič, L. (2013). Korolj Danilo Romanovič. Bila Cerkva: Vid. Pšonkivskij. [Александрович, В. - Войтович, Л. (2013). Король Данило Романович. Біла Церква: Вид. Пшонківський.]

Berežkov, N. G. (1963). Hronologija russkogo letopisanija, Moskva: Izdateljstvo Akademii Nauk SSSR. [Бережков, Н. Г. (1963). Хронология русского летописания, Москва: Издательство Академии Наук СССР.]

Dąbrowski, D. (2012). Daniel Romanowicz król Rusi (ok. 1201-1264). Biografia polityczna. Kraków: Avalon. 
Font, M. (1987). II. Szempontok III. Béla halicsi hadjáratainak kronológiájához, Acta universitatis de Attila Jozsef nominatae, Acta Historica, 84, 45-50.

Font, M. (1991). II. András orosz politikája és hadjartai. Századok, 1-2, 107-144.

Font, M. (2005), Árpád-házi királyok és Rurikida fejedelmek. Szeged: Szegedi Középkorász Mühely.

Foss, C. F. W. (1991) Galatia. in: Kazhdan, A. ed. (1991). Oxford Dictionary of Byzantium.

Oxford: Oxford University Press, 816.

Galović, T. (2010), Libellus Policorion - Rogovski kartular (diplomatičko-povijesna analiza). sv. I-II, doktorska disertacija, Filozofski fakultet Sveučilišta u Zagrebu. (pregled sažetka i bibliografske jedinice) Preuzeto sa: http://bib.irb.hr/prikazi-rad?rad=481427

Galović, T. (2012). Arhiv Rogovske opatije. Arhivski vjesnik, LV, 103-116.

Holovko, O. B. (2001). Knjaz Roman Mstislavič ta jogo doba. Narisi političnogo žittja Pivdennoi Rusi XII - počatku XIII stolittja. Kiiv: Stilos. [Головко, О. Б. (2001). Князь Роман Мстиславич та його доба. Нариси політичного життя Південної Русі ХII - початку ХІІІ століття. Київ: Стилос.]

Holovko O. B. (2006), Korona Danila Galickogo, Volinj i Galičina v deržavnopolitičnomu rozvitku Centraljno-Shidnoi Evropi rannogo ta klasičnogo serednjoviččja. Kijiv: Stilos. [Головко О. Б. (2006), Корона Данила Галицького, Волинь і Галичина в державно-політичному розвитку Центрально-Східної Свропи раннього та класичного середньовіччя, Київ: Стилос.]

Holovko, O. (2010), Vijna za „galicku spadščinu” (1187-1189). Knjaža doba: istorija $i$ kuljtura, 3, 116-132.] [Головко, О. (2010), Війна за „галицьку спадщину" (1187-1189). Княжа доба: історія $і$ культура, 3, 116-132.]

Hóman, B. (1939) Magyar történet. II. Hóman B. - Szekfü, Gy. eds. Budapest: Királyi Magyar Egyetemi Nyomda.

Hruševskij, M. (1901). Hronologija podij Galicko-Volinskoi litopisi, ZNTŠ, 41, 1-71. [Грушевський, М. (1901). Хронольогія подій Галицько-Волиньської лїтописи. ЗНТШ,. 41, 1-72.]

Hruševskij, M. (19932). Istorija Ukrajini-Rusi, т. III, Kijiv: Naukova dumka. [Грушевський, М. (1993²). Історія України-Русі, т. III, Київ: Наукова думка.]

Jurasov, M. (2013) Rolj Peremišlja v borbe Vladimira Jaroslaviča za vozvraščenie Galiča (1189-1190). In: Nagirnyy, V. - Pudłocki, T. (eds.). Przemyśl i ziemia przemyska $w$ strefie wpływów ruskich $X$ - połowa XIV w. Kraków: 
Towarzystwo Wydawnicze „Historia Iagellonica” z siedzibą w Instytucie Historii UJ, 67-77.[Юрасов, М. (2013) Роль Перемышля в борбье Владимира Ярославича за возвращение Галича (1189-1190). In: Nagirnyy, V. - Pudłocki, T. (eds.). Przemyśl i ziemia przemyska $w$ strefie wplywów ruskich $X$ - połowa XIV w. Kraków : Towarzystwo Wydawnicze „Historia Iagellonica” z siedzibą w Instytucie Historii UJ, 67-77.]

Klaić, V. (1988). Povijest Hrvata. I, Macan, T. prired. Zagreb: Nakladni zavod MH. Kotljar, М. (2002). Danilo Halickij, Kijiv: Alternativi. [Котляр, М. (2002). Данило Галицький, Київ: Альтернативи.]

Krip'jakevič, I. P. (1984). Galicko-Volinske knjazivstvo, Kijiv: Naukova dumka. [Крип'якевич, І. П. (1984). Галицько-Волинське князівство, Київ: Наукова думка.]

Kristó, Gy. (1986). Az Árpad-kor háborúi. Budapest: Zrínyi Katonai Kiadó. Kristó, Gy. - Makk F. (1981). III. Béla emlékezete, Budapest: Magyar Helikon.

Laurent, V. (1941). La Serbie entre Byzance et la Hongrie à la veille de la quatrième croisade, Revue Historique du Sud-Est Européen, 18, 109-129.

Majorov, A. V. (2001). Galicko-Volinskaja Rus: Očerki socialjno-političeskih otnošenij v domongolskij period: Knjaz, bojare i gorodskaja obščina. SanktPeterburg: Universitetskaja kniga. [Майоров, А. В. (2001). ГалицкоВольнская Русь: Очерки сочиально-политических отночений 6 домонгольский период: Князь, бояре и городская община. СанктПетербург: Университетская книга.]

Makk, F. (1982). III. Béla és Bizánc. Századok, 1, 33-61.

Makk, F. (1989). The Árpáds and the Comneni. Political relations between Hungary and Byzantium in the $12^{\text {th }}$ century, Budapest: MTA.

Makk, F. (2000). A tizenkettedik század törtenete. Budapest: Pannonica kiadó.

Moravcsik, Gy. (1953). Bizánc és a magyarság. Budapest: MTA.

Nagirnyj, W. (2011). Polityka zagraniczna ksiestw ziem halickiej $i$ wolynskiej $w$ latach 1198 (1199)-1264. Kraków: PAU.

Novak, G. (1957). Povijest Splita, knjiga prva (od prethistorijskih vremena do definitivnog gubitka pune autonomije 1420. god.). Split: MH.

Ostojić, I. (1964). Benediktinci u Hrvatskoj i ostalim našim krajevima. sv. II. Benediktinc u Dalmanciji. Split: Benediktinski priorat - Tkon.

Ostrogorski G. (1970). Urum-despot, Počeci despotskog dostojanstva u Vizantiji. u: Ostrogorski G. (1970). Iz vizantijske istorije, istoriografije i prosopografije. Sabrana dela, III, Beograd: Prosveta: 205-218. [Острогорски Г. (1970). Урум-деспот, Почеци деспотског достојанства у Византији. у: 
Острогорски Г. (1970). Из византијске историје, историографије и просопографије. Сабрана дела, III, Београд: Просвета: 205-218.]

Pašuto, V. T. (1968). Vnešnjaja politika Drevnej Rusi, Moskva 1968: Nauka. [Пашуто, В. Т. (1968). Внешняя политика Древней Руси, Москва 1968: Наука.]

Pauler, Gy. (1899). A magyar nemzet története az Árpádházi királyok alatt. II, Budapest: Athenaeum Irod. és Nyomdai Rt.

Radojčić, N. (1954). Promena u srpsko-madžarskim odnosima krajem XII veka. Glas SAN, 214, 1-21. [Радојчић, Н. (1954). Промена у српско-маџарским односима крајем XII века. Глас CAH, 214, 1-21.]

Riezler, S. (1869). Der Kreuzzug Kaiser Friedrichs I. Göttingen: Verlag Dietrich.

Vojtovič, L. (2008). Korolivstvo Rusi: fakti i mifi. in: Žernoklejev O. S. - Vološčuk M. - Gurak I. F. (eds.) (2008): Dorogičin 1253, Materiali mižnarodnoi naukovoi konferencii z nagodi 755-i ričnici koronacii Danila Romanoviča, Ivano-Frankivsk: LIK, 4-17. [Войтович, Л. (2008). Королівство Pусі: факти и міфи. in: Жерноклеєв О.С. - Волощук М. - Гурак I. Ф. (eds.)(2008): Дорогичинъ 1253, Матеріали міжнародної наукової конференції з нагоди 755-ї річниці коронації Данила Романовича, Ивано-Франківськ: ЛІК, 4-17.]

Vojtovič, L. (2015). Galič u političnomu žitti Evropi XI-XIV stolit, Ljviv: Institut ukrainoznavstva im. Ivana Krip'jakeviča. [Войтович, Л. (2015). Галич y політичному житті Європи XI-XIV століть, Львів: Інститут українознавства ім. Івана Крип' якевича]

Vološčuk, M. (2007). Problema legitimizacii vlasti vengerskogo korolja Endre II v Galickoj zemle (1205-1206). Slavjanskie čtenija, posvjašč. Dnju svv. Kirilla $i$ Mefodija, 5, 16-21. [Волощук, М. (2007). Проблема легитимизации власти венгерского короля Эндре II в Галицкой земле (1205-1206). Славянские чтения, посвящ. Дню свв. Кирилла и Мефодия, 5, 16-21.]

Vološčuk, M. (2008). Problema vasaljnoi (?) pidleglosti knjaziv Igorevičiv černigivskih vid ugorskogo korolja Endre II: džerela, istoriografija, korotka postanovka problemi. Ukrajinskij istoričnij zbirnik, 11, 18-25. [Волощук, M. (2008). Проблема васальної (?) підлеглості князів Ігоревичів чернігівських від угорського короля Ендре II: джерела, історіографія, коротка постановка проблеми. Український історичний збірник, 11, 1825.]

Vološčuk, M. (2010). Dominus noster Bela Galaciae Rex. Problema onovlennja titulu ugorskih koroliv v konteksti vijskovih podij rubežu 80-90 pp. XII st., in: 
Karpov V. V. - Gorelov V. I. - Moroz I. V. (2010). Voenna istorija Galičini ta Zakarpattja. Naukovij zbirnik. Materiali Vseukrajinsbkoi vijskovoistoričnoi konferencii. Ljviv, 15 kvitnja 2010 r. Ljviv: B.V., 63-66. [Волощук, M. (2010). Dominus noster Bela Galaciae Rex. Проблема оновлення титулу угорських королів в контексті військових подій рубежу 80-90 pp. XII ст., in: Карпов В. В. - Горєлов В. I. - Мороз I. В. (2010). Воєнна історія Галичини та Закарпаття. Науковий збірник. Матеріали Всеукраїнської військово-історичної конференції. Львів, 15 квітня 2010 р. Львів: Б. В., 63-66.]

Vološčuk, M. (2014). „Rus ”” v Ugorskomu korolivstvi (XI - druga polovinaXIV st.): suspiljno-politična rolj, majnovi stosunki, migracii, Ivano-Frankivsk: LilejaNV. [Волощук, М. (2010). „Русь” в Угорському королівстві (XI - друга половина XIV cm.): суспільно-політична роль, майнові стосунки, міграції, Івано-Франківськ: Лілея-НВ. ]

Włodarski, B. (1925). Polityka Ruska Leszka Bialego. Lwów: Archiwum Tow. Nauk. we Lwowie.

Włodarski, B. (1966). Polska i Ruś 1194-1340. Warszawa: PWN.

Zsoldos, A. (2011). Magyarország világi archontológiája 1000-1301. Budapest: MTA. 